\title{
Can Bioethanol Lead Pakistan Towards Sustainability and Prosperity? A Narrative Review
}

\author{
Abeer Mohsin ${ }^{*}$ and Syeda Zehratul Fatima
}

Jinnah University for Women, Karachi, Pakistan

\begin{abstract}
Economic recession, power and fuel shortage, waste management and pollution leading to global warming and climate change are few of the major issues faced by Pakistan, a developing country. These issues can be addressed to some extent by implementing policies and programmes by the government that will promote the development of the renewable energy sector in the country. Pakistan being an agricultural country has great potential to produce bioethanol, by using agricultural and municipal waste, and be able to fulfil its fuel requirements. Countries such as Canada, China and Brazil, the top producers of bioethanol in the world, can be followed as examples in terms of making policies for the growth and development of bioethanol industries. The government should make policies to replace traditional petroleum with ethanol-blended fuel to minimize the energy crisis and environmental pollution throughout the country.
\end{abstract}

Keywords: Renewable energy, pollution, economic growth, sustainable development goals, global warming, waste management.

\section{INTRODUCTION}

Leading and well developed countries around the globe including USA, Brazil, China, Australia, Thailand, Canada, Malaysia, etc. are investing their time and energy to find out renewable, cheaper and environmentally friendly alternatives of petroleum in view of the fact that oil reserves around the world are eventually running out [1]. The consumption of liquid fuels by the world is increasing day by day, it is estimated that the consumption of fuel by 2040 will increase to 115 million barrels per day as compared to 89 million barrels per day in 2013 [2]. The burning of this much fuel every day leads to the production of harmful gases in very large amounts, this pollution leads to global warming and climate changes taking place throughout the world drastically. Alternate fuels are being opted in view of the fact that the oil reserves throughout the world are exhausting and will eventually run out [3]. Biofuels are various types of fuels, synthesized from renewable sources, such as biogas, biodiesel and bioethanol. Of all the biofuels, bioethanol is the most feasible option that is gaining attention throughout the world. This is evident from the fact that the annual production of bioethanol across the globe increased to 87.2 million $\mathrm{m}^{3}$ in 2013 as compared to 28.5 million $\mathrm{m}^{3}$ in 2004 [1]. There are three types of bioethanol, classified on the basis of the raw material used for the synthesis and processes through which they are made, namely $1^{\text {st }}$ generation bioethanol, $2^{\text {nd }}$ generation bioethanol and $3^{\text {rd }}$ generation bioethanol [4].

Address correspondence to this article at the H\#476, D.O.H.S. Phase-1, Malir Cantonment, Karachi, Pakistan; Tel: +923433382419;

E-mail: abeermohsin123@gmail.com
Bioethanol blended with petroleum in different proportions is used as an alternative. E5 is a blend of $5 \%$ bioethanol with $95 \%$ petrol, which can be used in all sorts of vehicles without any alterations in the engine. Using E5 as fuel helps in the complete combustion of petrol and hence produces fewer greenhouse gases. E85 is $85 \%$ of bioethanol blended with $15 \%$ of petrol, it can only be used in flex-fuel vehicles (FFV) i.e. vehicles with modified engines so that they can work on more than one type of fuel [5]. FFVs were launched in Brazil in 2003 to encourage the use of biofuels [6]. Bioethanol is ethanol produced by the fermentation of sugar by saccharomyces cerevisiae, more commonly known as the baker's yeast [7]. It has a higher octane number [8] and allows the fuel to undergo complete combustion and produce less harmful gases [9]. The raw material used for the synthesis of bioethanol is agricultural waste or agricultural residue and municipal waste. All sorts of agricultural residues can be used to make bioethanol such as cane molasses, pseudostems, peels, seeds, residues left after harvesting various crops such as rice, cotton, wheat, etc. [10]. All of these residues are collectively called the biomass, which mostly comprises of lignocellulosic material that alone has the potential to produce around 442 billion litres of bioethanol globally [11]. The biomass is pretreated by acid hydrolysis to hydrolyze the non-fermentable sugars to fermentable form so that they can be fermented into ethanol [12]. Once the fermentation process is complete ethanol can be obtained through distillation. This biomass, if not used to make ethanol, is then mostly burned by the farmers on the fields to get rid of it, hence causing air pollution [13]. Waste management is a problem that 
can be solved to some extent if it is used in the right direction [14].

\section{THE FUTURE OF BIOETHANOL IN PAKISTAN}

Pakistan being an agricultural country has great potential to make bioethanol and use it as fuel instead of spending billions of dollars in importing petroleum from different parts of the world, mostly the Middle Eastern countries [8]. Some of the major crops and fresh produce of Pakistan include sugar cane, rice, cotton, maize, wheat, mangoes, oranges (kinnow), apples, onions potatoes, bananas, watermelons, etc.
According to the statistics provided by the Ministry of National Food Security \& Research Pakistan produces a total of about 7 million tons of fruit annually consisting of a huge variety such as 1.3 million tons of mangoes, 2.3 million tons of citrus fruit, 1.5 million tons of bananas and 0.5 million tons of melons. More than 7 million tons of vegetables and 2 million tons of condiments are produced in Pakistan annually [15].

All of these and many more fresh produces are a great source of biomass. Approximately 2.2 million hectares of land is used for the cultivation of wheat and

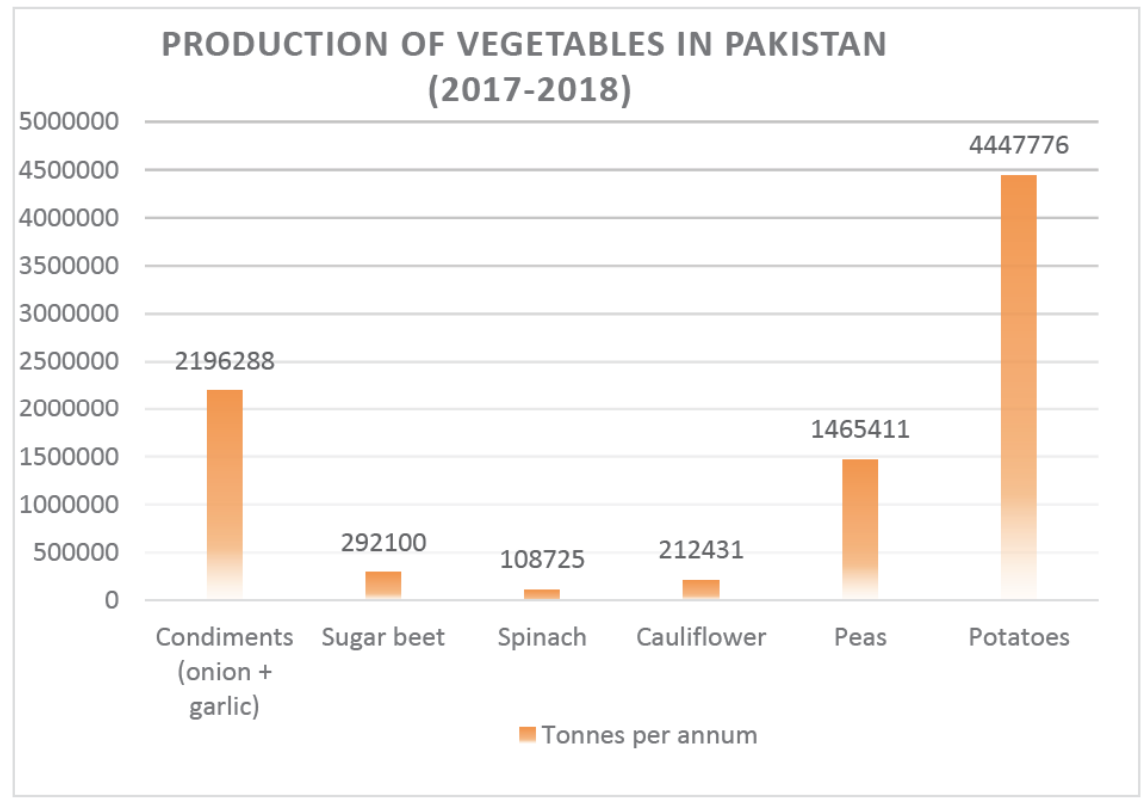

Figure 1: Production Of Vegetables In Pakistan According To The Report Presented By The Ministry Of National Food Security And Research Pakistan 2017-18.

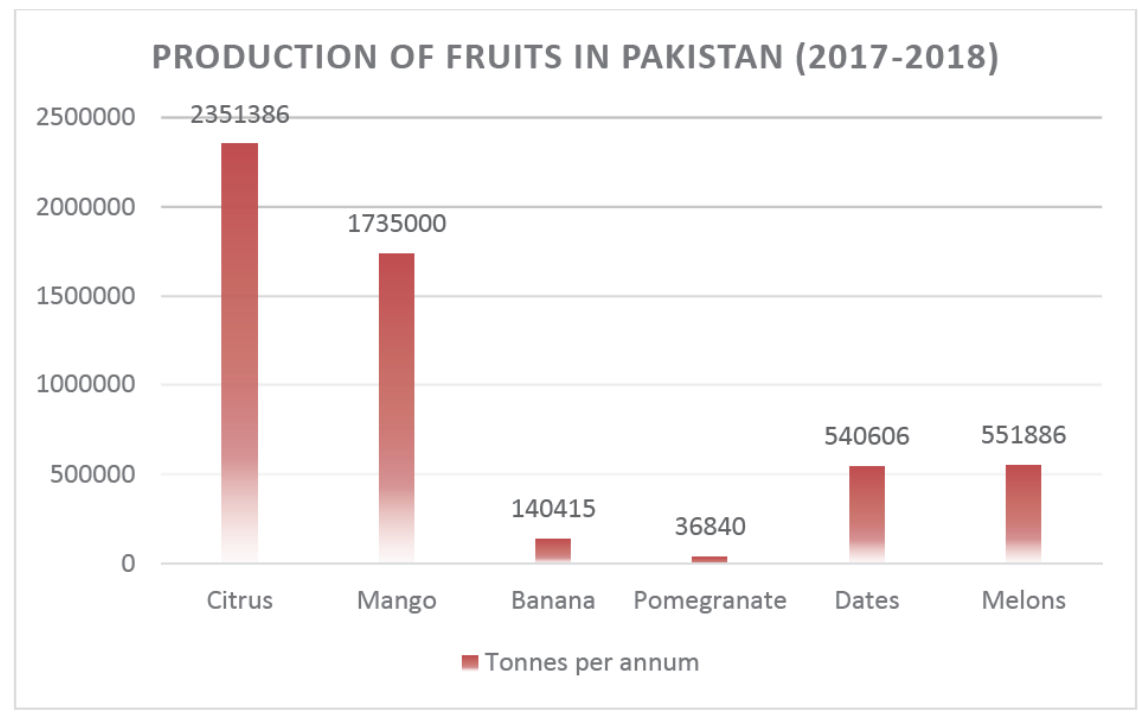

Figure 2: Production Of Fruits In Pakistan According To The Report Presented By The Ministry Of National Food Security And Research Pakistan 2017-18. 


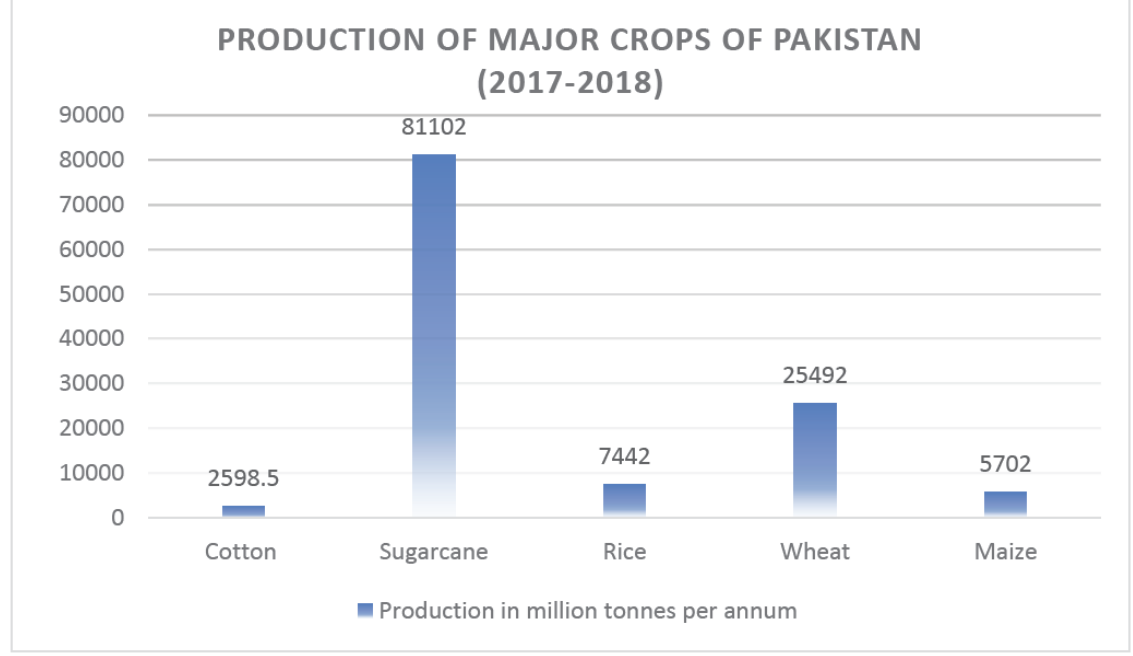

Figure 3: Production Of Fruits In Pakistan According To The Report Presented By The Ministry Of National Food Security And Research Pakistan 2017-18.

rice and up to 9 tons per hectare area of crop residue is produced annually [16]. The biomass obtained from the waste produced from these crops can be used to ferment large amounts of bioethanol to be used as fuel [17]. Agricultural and municipal wastes are two big sources of biomass that have enormous potential to be fermented into ethanol. Approximately 69 million tons of agricultural waste is produced in Pakistan annually [18], which mainly comprises of about 1.5 million tons of rice husk, 11.2 million tons of rice straw [19], 26.7 million tons of sugarcane baggage [20], 13 million tons of cotton stalk [21], etc. According to the government of Pakistan, 80,000 tons of municipal waste is generated in the country on a daily basis. On July 23,2019 , it was reported by the daily times that 48.5 million tons of municipal waste are generated annually in Pakistan. All of this municipal and agricultural waste collectively has great potential to be fermented into bioethanol.

\section{BENEFITS BIOETHANOL CAN REAP}

The benefits we can achieve from replacing biofuel with fossil fuels are not confined to one field but it is going to benefit us in many ways.

\section{Global Warming and Climate Change}

Using bioethanol will help us combat global issues like climate change and global warming. With time we humans who claim to have progressed and accelerated in the field of science and technology, have been damaging nature and the environment of our planet sometimes accidentally and most of the times deliberately. Climate change is something that in today's world no one can deny. According to a report published by BBC on September 30, 2019, a 315 billion tonne iceberg broke off the Amery ice shelf in Antarctica. It is said to be the biggest iceberg produced

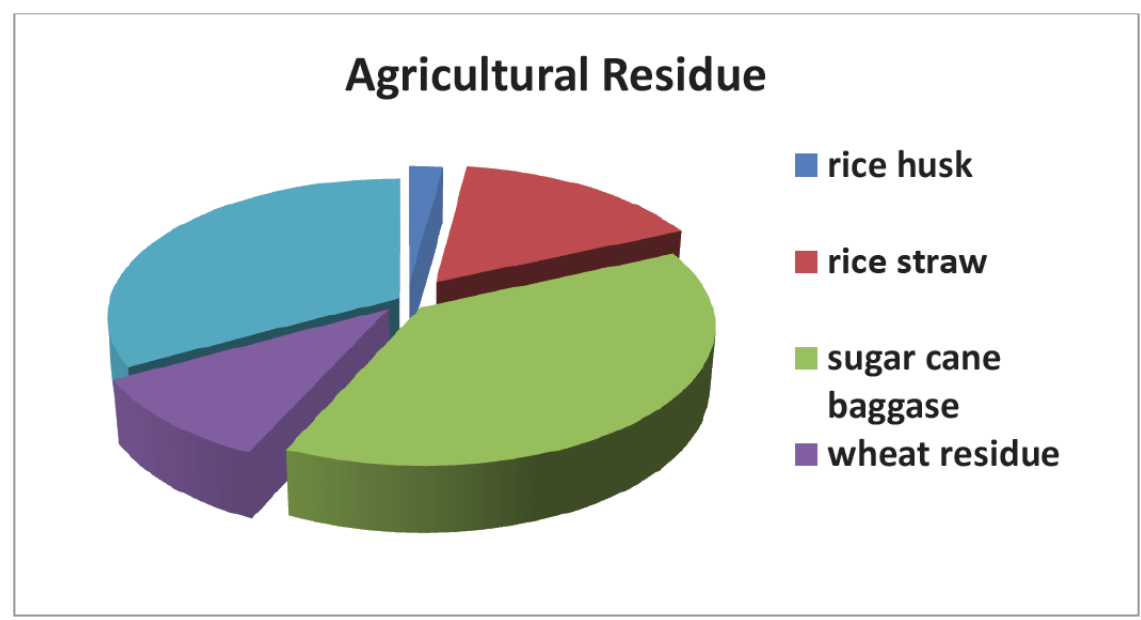

Figure 4: Representation Of The Agricultural Residue Generated Annually. 


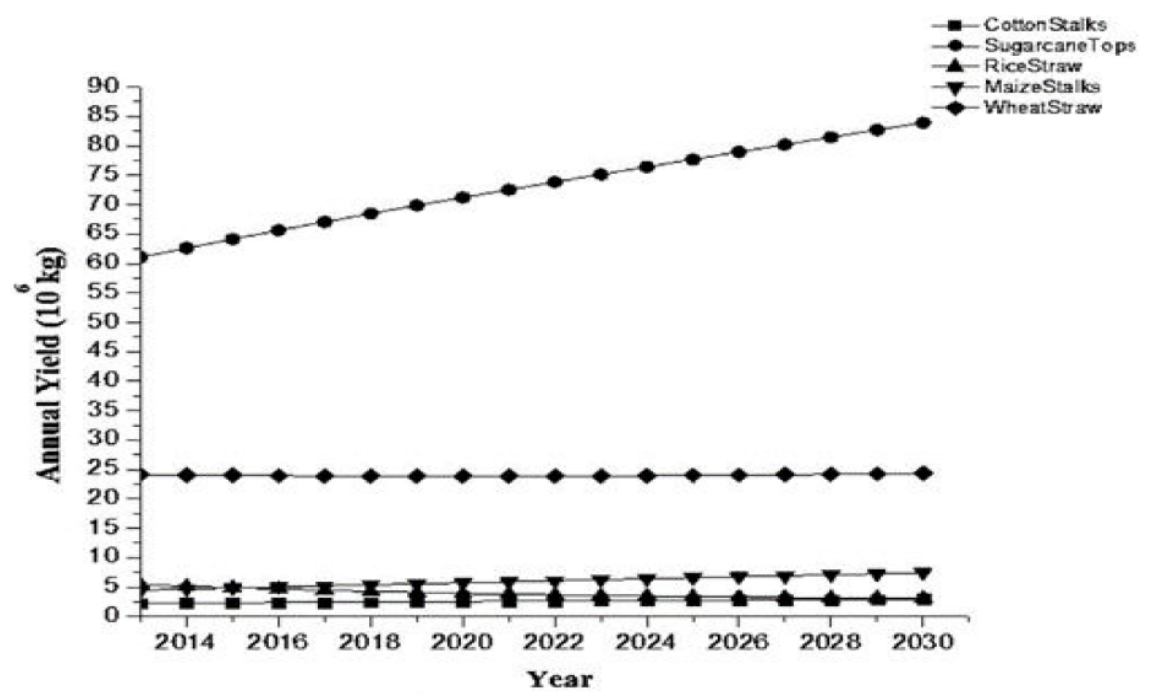

Figure 5: Feedstock's potential from 2013-2030 based upon the availability of crop residues such as wheat straw, rice straw, sugarcane tops, cotton stalks, and maize stalks in Pakistan [18].

in more than 50 years. Due to a rise in temperature globally, glaciers are melting fast, as national geographic reported the Alaskan glaciers are melting 100 times faster. The melting of glaciers at this rate is not only alarming because of the increasing water in seas and oceans but also it is leading towards the exposure of the hidden viruses and bacteria. A report launched by the food and agriculture organization of United Nations in February, 2019 under their project RSMOG (Remote sensing for Spatio-temporal mapping of smog) identified the potential factors causing smog includes the transport sector, the largest contributor followed by the industrial sector contributing up to $25 \%$ to air pollution and then the agriculture sector. The use of bad quality fuel has made both, the transport and industrial sector the top contributors in air pollution leading to smog. The burning of agricultural residues in fields has caused the agricultural sector to be a major source of air pollution.

All of these incidents are undeniable proofs of climate change and global warming which could make the existence of the human race questionable. Using fuels with a blend of bioethanol will help in preventing more damage to the environment as bioethanol has a higher octane number it allows the fuel to undergo complete combustion and less harmful gases are emitted from the vehicles, hence less air pollution [9].

\section{Pakistan's Economy and Power Shortage}

Pakistan is a developing country which is recovering from the effects of war against terrorism that the country had been fighting for the last fifteen years and

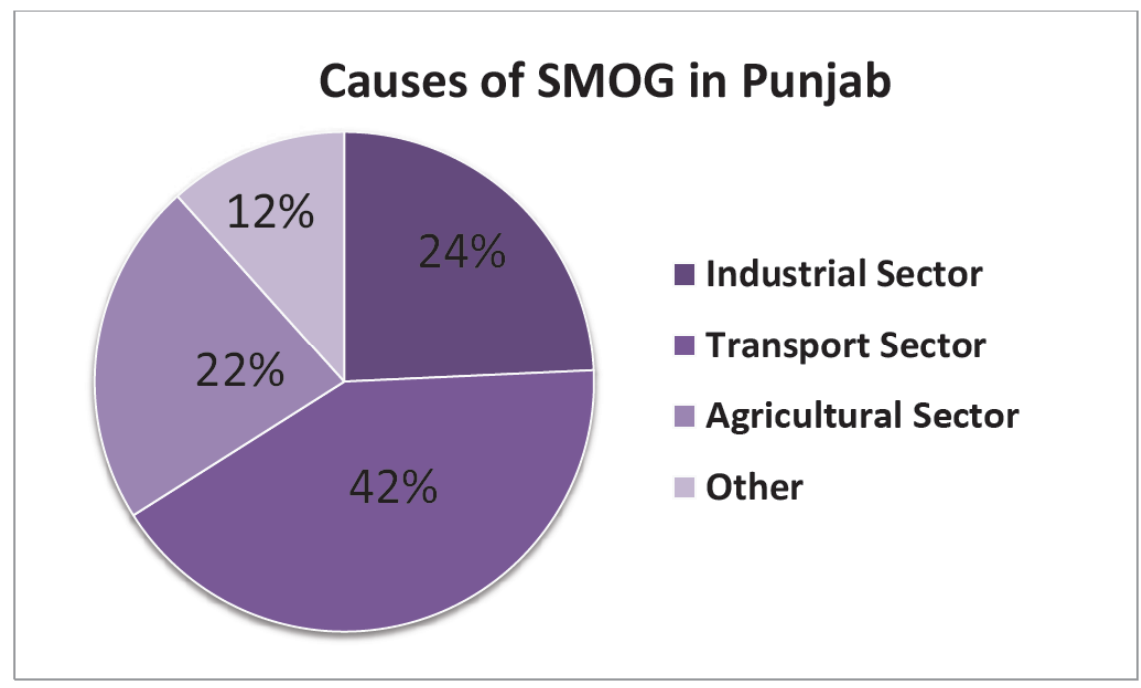

Figure 6: Sources of smog in Punjab according to the food and agriculture organization of the United Nations. 
has now successfully eradicated terrorism from the country, hence the economic condition of the country is not so strong. According to the Observatory Economic Complexity (OEC), the country spends approximately \$7.04billion annually on importing petroleum and $\$ 2.88$ billion on crude petroleum mainly from U.A.E., Afghanistan and Saudi Arabia, yet it is insufficient to meet the demands. Due to the shortage of power and fuel, a lot of industrialists have been forced to shut down their industries, which then leads to importing more goods and this is only leading the country towards a weaker economy [22]. Not only the economy is weakening and the country is getting in more and more debts day by day but also unemployment is a very prevalent issue in the country [23]. If all the agricultural waste/residue is used for the synthesis of bioethanol not only will we be able to solve the waste management issue to some extent, but also some part of the big chunk of the budget, that is used for importing fuel, can be saved and then can be used for the development of the country [24]. The shortage of power in the country can be decreased by making our own fuel and the conditions will attract industrialists to establish new industries and hence will provide new job opportunities for the people.

\section{Sustainable Development Goals}

Ever since the UN has proposed the 17 sustainable development goals researchers and scientists around the globe are working on ways to achieve them. Bioethanol is one such development that will help us in achieving many of the 17 sustainable development goals [25].

GOAL-1 NO POVERTY: as mentioned earlier setting up new industries will provide job opportunities for all and will hence help in decreasing poverty.

GOAL-7 AFFORDABLE AND CLEAN ENERGY: as the production of bioethanol requires minimal investment, it is very much affordable for all countries.

GOAL-8 DECENT WORK AND ECONOMIC GROWTH: with a decrease in the amount spent in imports, the economy of the country will flourish.

GOAL-13 CLIMATE ACTION: biofuels are environmentally friendly in two ways, one that it does not produce harmful gases when undergoes combustion and secondly, agricultural waste is used for its synthesis, hence waste recycled.

\section{Waste Management}

Pakistan is also one of the many countries of the world who is facing problems with disposing of their waste. $80 \%$ of the municipal waste comprises of fermentable sugars and lignocellulosic material which can be used to produce bioethanol [26]. Agricultural and municipal waste together can produce large amounts of bioethanol and save a large part of the budget [27]. If the waste produced by the country is pretreated and fermented into bioethanol not only will the issue of waste management be addressed to some extent but also it will help us combat economic issues in the country.

\section{PAKISTAN'S POSITION IN THE WORLD OF BIOETHANOL}

Pakistan State Oil (PSO) launched E10 gasoline in Karachi and Islamabad in July 2009. However, due to lack of support by the government they had to give up on the project. Today, more than 2.2 million tonnes of cane molasses is obtained annually in Pakistan as a by-product from sugar mills. This molasses is fermented into ethanol by the mill owners. However, instead of supplying it to the local market, ethanol worth millions of dollars is produced and exported to some of the most developed countries of the world. As reported by the Pakistan Ethanol Manufacturers Association (PEMA) ethanol worth $\$ 500$ million was exported in 2018. It was reported by DAWN news that according to the official figures 653,443 metric tonnes of ethanol was produced by the end of December 2018. According to OEC, the top export countries of Pakistan are the U.S., Germany, U.K., China and Afghanistan. No other work in this regard has been done yet at an industrial level even though we still have other raw material with great potential to produce bioethanol and use it as fuel to remove some burden of importing petroleum from our already very limited budget [8]. The manufacturing cost of bioethanol after the addition of other charges such as the wages of the operational staff, the cost of transport, marketing, capital-related investment charges, etc. is estimated to be Rs. 45/litre ( $\$ 0.53 /$ litre) which in comparison to petroleum is economy friendly [28].

\section{EXAMPLES TO BE FOLLOWED BY PAKISTAN}

Countries that are replacing fossil fuels with biofuels have policies made on the government level to support 
the purpose and make it successful. Laws and regulations have been made to ensure sustainable development of biofuels [29]. Following are the examples of a few of the many countries that are working on an environment-friendly energy alternate that can be followed:

\section{Brazil}

Today Brazil is the second-largest producer of bioethanol in the world, following the USA and the largest producer of bioethanol from sugarcane [30]. They started experimenting for fuel alternatives as early as in the 1920 and then more than 40 years ago they introduced the first government-level policy/program called the proalcool program in 1975 to substitute gasoline with bioethanol. Subsidies of the members of the government were abolished in order to support the program and invest in it. They then introduced flex-fuel vehicles (FFV) to promote the use of energy-efficient and eco-friendly vehicles [31]. Today more than $80 \%$ of the vehicles in Brazil are using biofuels [29]. The Brazilian government has always been busy in making new policies to flourish on renewable energy, today $50 \%$ of the energy used in Brazil is renewable. The government has enacted on the minimum $20 \%$ to a maximum $25 \%$ blending mandate to ensure the use of environmentally friendly energy as much as possible. Today the people of Brazil can choose between E27 and E100 to fuel up their cars [30].

\section{Thailand}

Thailand since a long time is encouraging and supporting the use of renewable energy and has been improving its policies in this regard. Many support programs have been introduced by the government to promote the cause including tax exemptions, a feed-inpremium (FIP)/ adder program introduced in 2006, feed-in-tariffs (FIT) in 2013, competitive bidding and the most recent policy enacted by the government is the alternative energy development plan (AEDP) in 2015 in which they target to increase renewable energy (electricity, heat, biofuels, etc.) to $30 \%$ of the country's total energy consumption by 2036 . The Thailand Board of investment supports alternative energy programs mostly in the form of tax exemptions, also the government demonstrates support by providing great privileges to renewable investment. The support and actions by the government have turned out to bear fruit in the form of an increase in renewable energy up to $11.7 \%$ in 2015 alone on year by year basis out of which almost $20 \%$ is used for biofuel production. The policies made by the government in this regard are to address the challenges that renewable energy projects face on early developmental stages. Renewable energy is said to be the top priority of Thailand's government [32].

\section{Canada}

Greenhouse gas (GHG) emissions is a matter of concern for all of us and many countries like Canada are intensely researching on and commercializing renewable fuels to reduce GHG emissions. Canada established the bioenergy sector as an opportunity for sustainable economic development with auxiliary advantages (employment, health, environment, waste management, secured energy supply, etc.) almost 2 decades ago. Regulations on renewable fuel content have been implemented in Canada over the last 10 years with the objective of decreasing GHG emissions. Today, approximately $6 \%$ of Canada's total energy supply accounts for biomass. Environment and climate change Canada developed new policies under the Canadian environment protection Act to reduce GHG emissions by 30 megatonnes annually by 2030 with the help of increased use of low carbon fuels. This policy came into effect in 2015 and has led to show fruitful results in the form of a reduction in GHG emissions by 4.4 megatonnes and increased use of biofuel up to 2800 million litres ethanol annually. Many programs have also been put into effect by the federal government to provide financial support for the development of the biofuels industry in Canada. The national renewable diesel demonstration initiative, ecoENERGY for biofuels, NextGen Biofuel funds, Sustainable development technology funds and the Ethanol expansion programme are few of the many such programs [33]. In June 2016, during the amigo's summit in Ottawa, USA, Canada and Mexico committed to generating $50 \%$ of their combined energy from clean sources by 2025 [34]. All of these and many more policies that are effective in Canada are helping the renewable energy sector of the country to flourish. Canada is on the road towards achieving enormous benefits by using clean and green energy.

\section{China}

Considering the problems associated with fossil fuels, mainly increasing energy shortage and environmental pollution, China is carrying out tremendous efforts to encourage and develop alternate, clean and renewable energies. They spent billions of dollars on the development of biofuels 


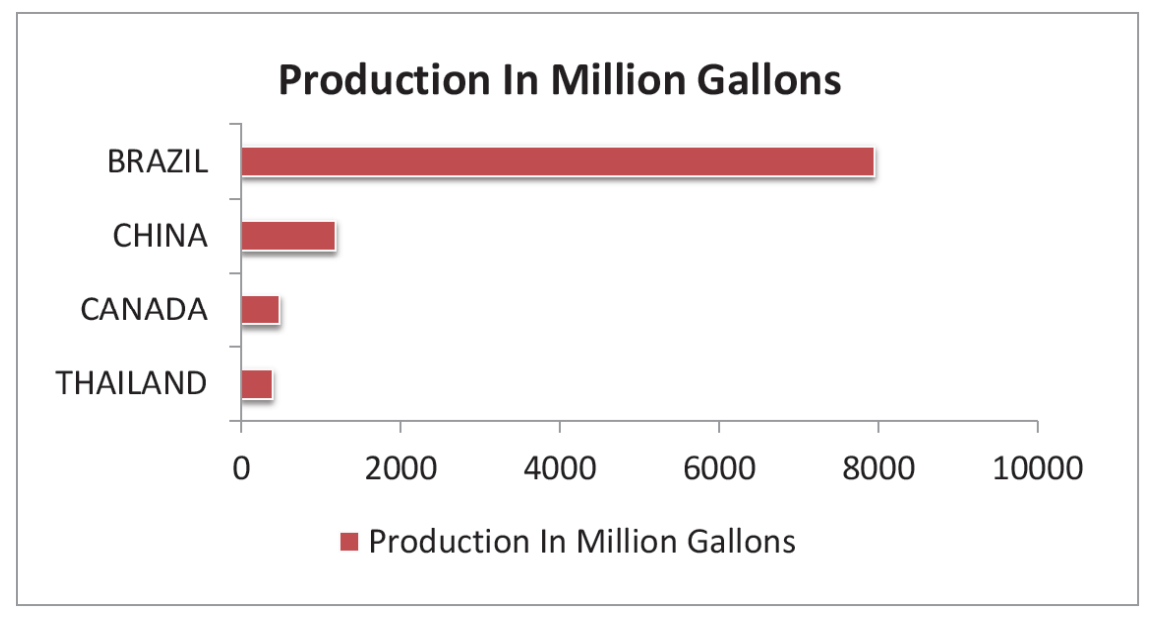

Figure 7: Ethanol Fuel Production In Top Countries In 2018 According To The Data Published By Statista.

(bioethanol and biogas). The interest of the country in finding alternative energy sources dates back to the 1970s when they launched a massive biogas campaign. However, they started their pilot bioethanol programme in 2002 and it began production in 2003. The immense support and favourable policies by the government resulted in an increase in the production of bioethanol from 30,000 tonnes in 2002 to almost 1.9 million tonnes in 2010. The Chinese government has been coming up with various policies to promote the development of renewable energy plants, one of which, enacted in 2012, is the renewable energy development $12^{\text {th }}$ five-year plan. According to this plan, their objective is to increase the bioethanol production up to 4 million tonnes annually. Today, china is the thirdlargest producer of bioethanol globally [35].

\section{CONCLUSION}

Pakistan is a developing country facing many problems. However, the solutions to most of the problems lie within the country. Young and dedicated researchers of the country are tirelessly working day and night in search of better, feasible and affordable solutions. Despite the availability of raw material and the abundance of great potential in the country, all the research done is limited to labs and journals. The government of the country needs to play its role and introduce policies and incentives which would attract industrialists to collaborate with researchers to implement all those brilliant ideas on the commercial level. The Pakistani government should make policies that should impose the use of petrol blended with bioethanol. Tax-free programs, easy to achieve funds and incubation centres are a few examples of what the government should promote and work on. Just like other countries, which are prospering on the basis of renewable energy in a clean and green environment, only because of the policies and programs they enacted to support the developing renewable energy industries. We should take them as an example and follow their footsteps on the road towards prosperity. There is no harm or shame in taking inspiration from others as stated by the very famous comedian and philanthropist, Junaid Akram if one cannot come up with his or her own ideas to solve a problem we can look around and take inspiration from others. We need to join hands and make efforts to minimize the harm caused to our planet by the activities done on a daily basis or else gradually the conditions of the earth will reach a point where human survival might not be possible.

\section{REFERENCES}

[1] Moya D, Aldás C, López G, Kaparaju P. Municipal solid waste as a valuable renewable energy resource: a worldwide opportunity of energy recovery by using Waste-To-Energy Technologies. Energy Procedia 2017; 134: 286-95. https://doi.org/10.1016/j.egypro.2017.09.618

[2] Choi IS, Lee YG, Khanal SK, Park BJ, Bae HJ. A low-energy, cost-effective approach to fruit and citrus peel waste processing for bioethanol production. Applied Energy 2015; 140: $65-74$.

https://doi.org/10.1016/j.apenergy.2014.11.070

[3] Hassan $\mathrm{MH}$, Kalam MA. An overview of biofuel as a renewable energy source: development and challenges. Procedia Engineering 2013; 56: 39-53. https://doi.org/10.1016/j.proeng.2013.03.087

[4] Dragone G, Fernandes BD, Vicente AA, Teixeira JA. Third generation biofuels from microalgae 2010; 978-84-614-61950 .

[5] De Melo TC, Machado GB, Belchior CR, Colaço MJ, Barros JE, de Oliveira EJ, de Oliveira DG. Hydrous ethanol-gasoline blends-Combustion and emission investigations on a FlexFuel engine. Fuel 2012; 97: 796-804. https://doi.org/10.1016/i.fuel.2012.03.018

[6] De Melo TC, Machado GB, Machado RT, Belchior CR Pereira PP. In Cylinder Pressure Curve Simulation On Multifuel Engines-A Comparison Between A Polytrophic And 
General Thermodynamic Model For Gasoline, Ethanol And Natural Gas. SAE Technical Paper 2007. https://doi.org/10.4271/2007-01-2820

[7] Azhar SH, Abdulla R, Jambo SA, Marbawi H, Gansau JA, Faik AA, Rodrigues KF. Yeasts in sustainable bioethanol production: A review. Biochemistry and Biophysics Reports 2017; 10: 52-61.

https://doi.org/10.1016/j.bbrep.2017.03.003

[8] Arshad M. Bioethanol: A sustainable and environment friendly solution for Pakistan. A Scientific J. COMSATS-Sci Vision 2010; 2011: 16-7.

[9] Ozturk I. Utilizing biofuels for sustainable development in the panel of 17 developed and developing countries. Gcb Bioenergy 2016; 8(4): 826-36.

https://doi.org/10.1111/gcbb.12287

[10] Ingale S, Joshi SJ, Gupte A. Production of bioethanol using agricultural waste: banana pseudo stem. Brazilian Journal of Microbiology 2014; 45(3): 885-92.

https://doi.org/10.1590/S1517-83822014000300018

[11] Aditiya HB, Chong WT, Mahlia TM, Sebayang AH, Berawi MA, Nur $\mathrm{H}$. Second generation bioethanol potential from selected Malaysia's biodiversity biomasses: A review. Waste Management 2016; 47: 46-61.

https://doi.org/10.1016/j.wasman.2015.07.031

[12] Demirbas A. Biofuels sources, biofuel policy, biofuel economy and global biofuel projections. Energy conversion and management 2008; 49(8): 2106-16.

https://doi.org/10.1016/j.enconman.2008.02.020

[13] Ahmed T, Ahmad B, Ahmad W. Why do farmers burn rice residue? Examining farmers' choices in Punjab, Pakistan. Land Use Policy 2015; 47: 448-58.

https://doi.org/10.1016/j.landusepol.2015.05.004

[14] Priyanka M, Kumar D, Shankar U, Yadav A, Yadav K. Agricultural Waste Management for Bioethanol Production. InBiotechnology: Concepts, Methodologies, Tools, and Applications. IGI Global 2019; pp. 492-524.

https://doi.org/10.4018/978-1-5225-8903-7.ch019

[15] Ministry of National Food Security \& Research. Fruit, Vegetables and Condiments Statistics of Pakistan 2015-16. Islamabad: Government of Pakistan, 2016.

[16] Khaliq A, Matloob A, Hussain A, Hussain S, Aslam F, Zamir $\mathrm{SI}$, Chattha MU. Wheat Residue Management Options Affect Crop Productivity, Weed Growth, and Soil Properties in Direct-Seeded Fine Aromatic Rice. CLEAN-Soil, Air, Water 2015; 43(8): 1259-65.

https://doi.org/10.1002/clen.201400776

[17] Arumugam R, Manikandan M. Fermentation of pretreated hydrolyzates of banana and mango fruit wastes for ethanol production. Asian J Exp Biol Sci 2011; 2(2): 246-56.

[18] Tayyab M, Noman A, Islam W, Waheed S, Arafat Y, Ali F, Zaynab M, Lin S, Zhang H, Lin W. Bioethanol production from lignocellulosic biomass by environmentfriendly pretreatment methods: A Review. Applied Ecology and Enviromental Research 2018; 16(1): 225-49.

https://doi.org/10.15666/aeer/1601_225249

[19] Irfan M, Riaz M, Arif MS, Shahzad SM, Saleem F, van den Berg L, Abbas F. Estimation and characterization of gaseous pollutant emissions from agricultural crop residue combustion in industrial and household sectors of Pakistan. Atmospheric environment 2014; 84: 189-97.

https://doi.org/10.1016/j.atmosenv.2013.11.046

[20] Pakistan economy survey 2017-2018, Chapter 2, Agriculture.

[21] Bano A, Irfan M. Alkali pretreatment of cotton stalk for bioethanol. Bangladesh Journal of Scientific and Industrial Research 2019; 54(1): 73-82.

https://doi.org/10.3329/bjsir.v54i1.40733
[22] Naqvi SR, Jamshaid S, Naqvi M, Farooq W, Niazi MB, Aman Z, Zubair M, Ali M, Shahbaz M, Inayat A, Afzal W. Potential of biomass for bioenergy in Pakistan based on present case and future perspectives. Renewable and Sustainable Energy Reviews 2018; 81: 1247-58. https://doi.org/10.1016/j.rser.2017.08.012

[23] Abbas A, Yang M, Yousaf K, Khan KA, lqbal T, Hassan SG. Comparative analysis of energy use efficiency in food grain production systems of Pakistan. Fresen Environ Bull 2018; 27: 1053-9.

[24] Gebregergs A, Gebresemati M, Sahu O. Industrial ethanol from banana peels for developing countries: Response surface methodology. Pacific Science Review A: Natural Science and Engineering 2016; 18(1): 22-9. https://doi.org/10.1016/j.psra.2016.06.002

[25] Gaol RL, Octavian A, Kuntjoro YD. Strategies to Improve Bioethanol Utilization in Indonesia.

[26] Saini JK, Saini R, Tewari L. Lignocellulosic agriculture wastes as biomass feedstocks for second-generation bioethanol production: concepts and recent developments. 3 Biotech 2015; 5(4): 337-53.

https://doi.org/10.1007/s13205-014-0246-5

[27] Hafid HS, Shah UK, Baharuddin AS, Ariff AB. Feasibility of using kitchen waste as future substrate for bioethanol production: a review. Renewable and Sustainable Energy Reviews 2017; 74: 671-86. https://doi.org/10.1016/j.rser.2017.02.071

[28] Khichi AH. Bioethanol and Biodiesel from Second Generation Feedstocks: A Promising Solution to Energy Shortages in Pakistan. Proceeding of the Pakistan Academy of Sciences 2017; 54(2): 79-88

[29] Su Y, Zhang P, Su Y. An overview of biofuels policies and industrialization in the major biofuel producing countries. Renewable and Sustainable Energy Reviews 2015; 50: 9911003.

https://doi.org/10.1016/..rser.2015.04.032

[30] Cortez LA, Baldassin Jr R. Policies Towards Bioethanol and Their Implications: Case Brazil. InGlobal Bioethanol Academic Press 2016; pp. 142-162. https://doi.org/10.1016/B978-0-12-803141-4.00006-X

[31] Gasparatos A, Stromberg P, editors. Socioeconomic and environmental impacts of biofuels: Evidence from developing nations. Cambridge University Press 2012. https://doi.org/10.1017/CBO9780511920899

[32] Renewable Energy Agency, International. Thailand Renewable Energy Outlook Based on Renewables Readiness Assessment and REmap analysis 2017; 978-929260-035-8.

[33] Littlejohns J, Rehmann L, Murdy R, Oo A, Neill S. Current state and future prospects for liquid biofuels in Canada. Biofuel Research Journal 2018; 5(1): 759-79. https://doi.org/10.18331/BRJ2018.5.1.4

[34] Pischke EC, Solomon B, Wellstead A, Acevedo A, Eastmond A, De Oliveira F, Coelho S, Lucon O. From Kyoto to Paris: Measuring renewable energy policy regimes in Argentina, Brazil, Canada, Mexico and the United States. Energy Research \& Social Science 2019; 50: 82-91. https://doi.org/10.1016/i.erss.2018.11.010

[35] Hongzhou Z. Development of biofuels in China: Progress, government policies and future prospects. The Copenhagen Journal of Asian Studies 2015; 33(1): 40-63. https://doi.org/10.22439/cjas.v33i1.4811 